\title{
Tunceli ili merkez ilçesi yapılarındaki ateş bacalarının teknik analizi
}

\author{
Seyhan YARDIMLI ${ }^{1, *}$, Murat DAL ${ }^{2}$ \\ ${ }^{1}$ İstanbul Aydın Üniversitesi, Mimarlı ve Tasarım, Fakültesi, Mimarlık Bölümü, İstanbul. \\ ${ }^{2}$ Munzur Üniversitesi, Mühendislik Fakültesi, İnşaat Mühendisliği Bölümü, Tunceli.
}

Geliş Tarihi (Recived Date): 23.02.2017

Kabul Tarihi (Accepted Date): 12.04.2017

\section{Özet}

İnsanların sağllkl yaşayabilmeleri için en temel gereksinimlerinden biri barınmadır. Bu koşulun sağlanabilmesindeki önemli faktörlerden biri de gerekli isıl konforu yerine getirebilmektir. Bunun için yapılarda çeşitli ısitıcılara yer verilmekle birlikte özellikle kırsal alanlarda soba kullanılmaktadır. Sobadaki yakıtın yanması sırasında oluşan karbonmonoksitin dışarı atılması baca elemanı ile sağlanmaktadır. Baca bu işlevi yerine getiremediğinde ise insan să̆lı̆̆ını tehdit eden bir yapı elemanına dönüşmektedir. Günümüzde gelişen ihtiyaç ve teknik olanaklar çerçevesinde pek çok baca tipi ile karşılaşılmakla birlikte burada sadece ateş bacaları ele alınmıştır. Çalışmada yapıların sağlıklı ısıtılabilmeleri için gerekli ateş bacası düzenlemelerinin neler olabileceğini ortaya koymak ve karşılaşılan uygulama sorunlarına dikkat çekmek amaçlanmıştır. Çalışma İngiliz Baca ve Şömine Üreticileri Derneği, ülkemizde bulunan Baca Imalatçıları ve Uygulayıcıları Derneği, Çevre ve Şehircilik Bakanlı̆̆ Yapı Malzemeleri Yönetmeliği (89/106/EEC) ve bu konuda yapılmış yayınlara değinme, mevcut yapılar üzerinde incelenen bacaların olumlu ya da olumsuz yönlerini irdeleme yöntemleri ile yürütülmüş̧ür. Çalışma sürecinde ateş bacalarının yapımı hakkında göz önünde bulundurulması gereken prensiplere yer verilmiş, kullanılan malzeme ve formlara değinilmiştir. Bacaların binanın neresinde planlanması gerektiği, çatıda yükseklik ve konum olarak nasıl yerleştirileceği, çatı elemanlar ile ilgili detaylandırılma özellikleri, suya ve ısıya karşı yalıtım gerekliliği, dumanı çekme açısından diğer binalar ile bulunması gereken mesafeler belirtilerek, kullanımında dikkat edilecek noktalar vurgulanmış ve metin tamamlanmıştır.

Anahtar kelimeler: Baca yapımı, baca yükseklikleri, ateş bacası, baca malzemeleri.

\footnotetext{
* Seyhan YARDIMLI, seyhanyardimli@aydin.edu.tr, http://orcid.org/0000-0001-7186-9000 Murat DAL, muratdal@munzur.edu.tr, http://orcid.org/0000-0001-5330-1868
} 


\title{
The technical analysis of the fireplace chimneys in Tunceli, central district.
}

\begin{abstract}
People need to have shelter, which is one of the basic requirements required in order to maintain healthy lifestyles. We use chimney elements in these habitations in order to ensure thermal comfort. There are various heaters in the buildings, but stoves are used especially in rural areas. Chimneys need to facilitate the outdoor discharge of carbonmonoxide, which is generated during the burning process and which causes poisoning. This structure element can constitute a threat to people's health whenever it doesn't fulfill this function. Several types of chimneys are encountered within the scope of developing needs and technical possibilities. Only fireplace chimneys are covered in this study. The objective of this study is to put forward what features are necessary for chimneys to heat structures in a healthy manner. The study was carried out by means of examining the positive and negative aspects of structure chimneys around us, while touching upon standards and welding scans, considering the regulations of BFCMA British Flue and Chimney Manufacturers Association, Ministry of Environment and Urban Planning Building Materials Regulation and The Chimney Manufacturers and Practitioners Association. The study also covers principles that need to be considered in regards to the construction of fireplace chimneys, as well as touching upon the forms and materials to be utilized. Matters such as where chimneys need to be planned out in buildings, how they should be positioned and their heights on roofs, detailing features regarding the roof elements, the necessity for moisture and heat insulation, indicating the distances that must be maintained with neighboring buildings so that they don't draw in the smoke, then the text was concluded.
\end{abstract}

Keywords: Chimney construction, chimney heights, fireplace chimney, chimney materials.

\section{Giriş}

İnsanların yaşama mekânlarındaki ısıl konfor, sağlık açısından oldukça önemlidir. Gerekli 1sıl konforun gerçekleştirilebilmesi için ülkemizde kullanılan en yaygın yöntemler doğalgaz ile kömür ve odun gibi katı yakıtın yakılmasıyla elde edilen isı enerjilerinin kullanılmasıdır. Doğal gaz, kömür, odun vb. yapısında karbon bulunan yakıtların yanması sürecinde karbonmonoksit gazı ortaya çıkmaktadır. Yanma sırasında ortaya çıkan karbonmonoksit gazı renksiz, kokusuz ve akciğerler tarafindan kolayca emilen zehirli bir gazdır [1]. Bu zararlı gazı insanların soluması ise hastalıklara ve hatta ölümlere neden olmaktadır [2]. Sadece ülkemizde değil dünyada pek çok ülkede bu sorunla karşılaşılmaktadır. İngiltere ve Galler'de her yıl 1000 kişi hayatını karbonmonoksit zehirlenmesi nedeniyle kaybetmektedir. Kuzey Amerika'da 19971998 kışında kar fırtınasında zayıf havalandırma nedeniyle karbonmonoksit zehirlenmesiyle çok sayıda ölüm olmuştur. Amerika'da 1979-1988 yı1ları arasında 11 547 karbonmonoksit zehirlenmesi nedeniyle ölüm rapor edilmiş ve bunun \% 18'i gaz yakıtlı 1sıtıcılardan kaynaklanmıştır [3]. Ülkemizde de özellikle kırsal alanlarda ısınma ihtiyacı katı yakıtın sobalarda yakılması ile karşılanmaktadır. Yanma sürecinde ortaya çıkan bu zararlı gaz baca ile yaşanan ortamdan uzaklaştırılmaktadır. Binalarda bulunan 
baca bu noktada önem kazanmaktadır. Bacalar standartlara uygun yapılmadığında gaz atış1 yeterli düzeyde sağlanamaz ise zehirlenme ve ölümler ile karşılaşılabilmektedir.

Günümüzde artan gereksinimler doğrultusunda içinde yaşadığımız binalarda farklı amaçlarla kullanılan ateş, havalandırma, tesisat, çöp bacaları gibi pek çok baca çeşidi bulunmaktadır. $\mathrm{Bu}$ çalışmada ateş bacaları ele alınmıştır. Ateş bacaları ülkemizde yaygın olarak sobaların bağlandığı bacalar olmakla birlikte şömine ya da geleneksel yapılarımızda karşılaştığımız ocak elemanlarını da kapsamaktadır. Ateş bacalarının yapımında bina içindeki planlama, bina dışına çatıdan çıktıkları yer, baca yüksekliği ve uygulanma şartları gibi pek çok faktör bacaların sağlıklı çalışabilmesi açısından önem taşımaktadır. Baca yapımının sağlıklı ısınabilme ve yaşayabilme açısından oldukça önemli olmasına karşın çevremize bakıldığında pek çok bina bacasının gerekli standartlara uymadığı görülebilmektedir. Buna bağlı olarak da ülkemizde yüzlerce zehirlenme ve ölümle sonuçlanan olaylara rastlanılmaktadır [4].

Ateş bacaları ile ilgili çalışmalara bakıldı̆̆ında; Oymanel [5] yapı malzeme ve elemanlarının dayanıma etkisinden söz ederken yangın dayanımı açısından yapı elemanları ele alındığında baca içinde biriken kurumun saf karbon ve yanıcı olduğu dolayısıyla yangın açısından önemi belirtilmiştir. Uludağ [6] baca türlerine yer verilmiş, çekiş sorunlarına ve yapım sürecinde yapılan yanlışlıklara değinilmiş, iyi bir baca üretiminin malzeme açısından nasıl olması gerekliliği ile seramik, metal ve plastik baca elemanlarının örnekleri ele almıştır. Arıoğlu ve Hatipoğlu [7] çok katlı yapılarda şönt baca yapımı ele alınmış, konut ve benzeri binalarda bacaların tasarım ve yapım kurallarına ve TS 11386'daki bacalardan beklenen özelliklere değinilmiştir. Çok katlı yapılarda görülen şönt baca üretim hataları ve çözümlerine yer verilmiştir.

\section{Materyal ve metot}

Çalışmada, Tunceli merkez ve merkez köylerinde gözlem yapılmış, fotoğrafla durum tespit edilmiş, literatür taraması ile ateş bacaları hakkında yapılmış önceki çalışmalar araştırılmış, elde edilen bilgiler ve tespit edilen ateş bacası sorunları belirlenerek analiz edilmiştir. Gözlem sürecinde kent merkezi ve merkez köylerdeki konutlar, işyeri yapıları ve resmi yapılar üzerinde tespitler yapılmıştır. Çalışmada ele alınan yapıların bulunduğu bölge karasal iklim özelliği taşımakta ve yaygın olarak kiremit, galvaniz sac gibi çatı örtüleri kullanılmaktadır. Bu çatı özelliği de baca yapımında bazı detayların bulunması gerekliliğini getirmektedir. Yapılan çalışma mevcut çatı özelliklerine göre ele alınmış ve değerlendirilmiştir.

\section{Baca uygulamalarında önemli noktalar}

Ateş bacalarının yapımı pek çok açıdan önem taşımaktadır. Standartlara uygun yapılmış bir baca gerekli duman çekişini iyi bir şekilde sağlamakta ve iyi yanma ile hem iyi kalori elde edilmekte hem de zehirlenme riski ortadan kalkmakta ya da en aza indirilmektedir. Burada baca yapımındaki önemli noktalara sırası ile değinilmektedir.

\subsection{Baca yapımında kullanılan malzemeler ve formlar}

Ülkemizde duman bacası yapımı tuğla ya da kullanılan yapı malzemesinin örülürken boşluk bırakılması şeklinde ya da bu amaçla üretilmiş hazır baca elemanlarının 
kullanılması ile gerçekleştirilmektedir. Yaygın olarak içi delikli tuğla kullanılmaktadır (Şekil 1).
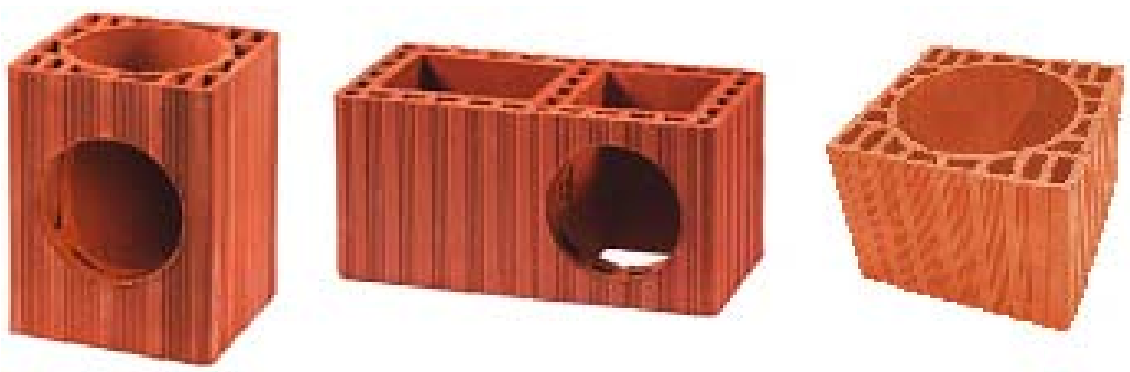

Şekil 1. Baca yapımında kullanılmak üzere üretilmiş tuğla örnekleri.

Tuğlaların baca yapımında örülmeleri sırasında iç bölümlerinde pürüz ya da artık malzeme kalmaması için baca deliğine bir kalıp konması ve tuğla örgüsü devam ettikçe kalıp yukarı çekilerek iç bölümde pürüzsüz yüzey oluşturulması bacanın iyi çekmesini sağlayan bir yöntemdir (Şekil 2) [8].

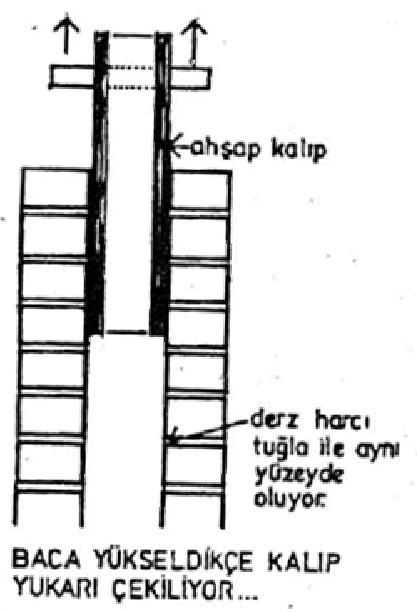

Şekil 2. Baca iç yüzeyinde düzgün yüzey oluşturmak amaçlı kalıp kullanımı [8].
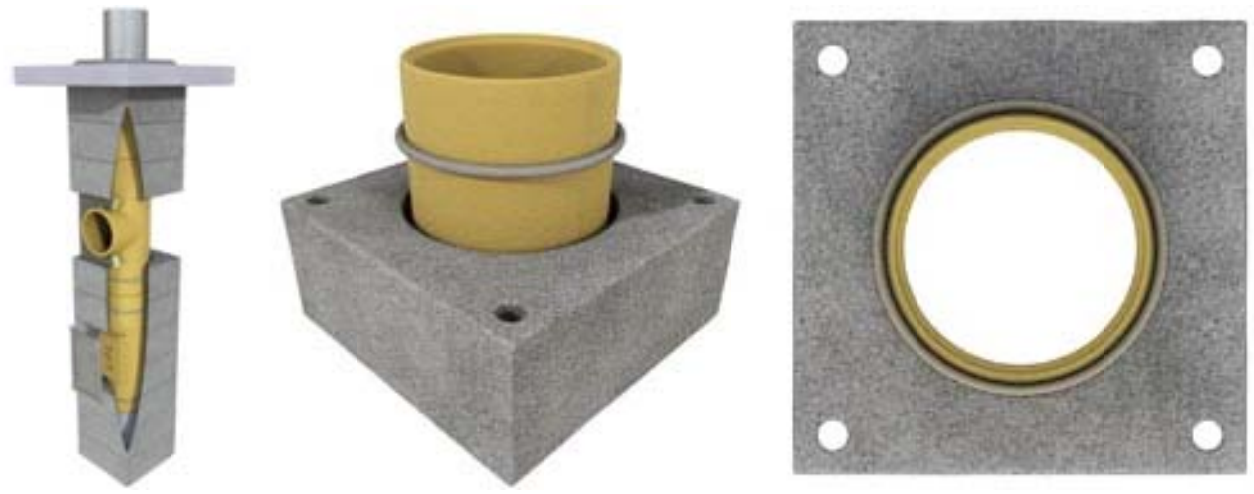

Şekil 3. Ülkemizde üretilen seramik baca elemanı [10].

2007 yılında yürürlüğe giren, Çevre ve Şehircilik Bakanlığı Yap1 Malzemeleri Yönetmeliği (89/106/EEC)'ne göre duman bacalarında da doğal gaz bacalarında da metal ve seramik baca kullanılması gerekliliği getirilmiş ancak uygulamaya henüz tam 
olarak geçirilememiştir. Şekil 3'te bu yönetmeliğe göre üretilmiş baca elemanı görülmektedir $[9,10]$.

İngiltere ve Avrupa standartlarında kullanılan malzemelere bakılacak olursa kil, pomza ve beton malzemeden yapılan baca elemanları ile çelik baca elemanları kullanılmaktadır (Şekil 4)[11].

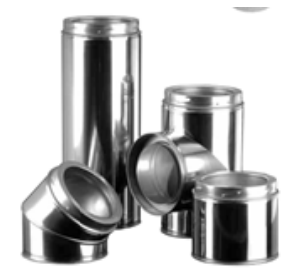

(a)

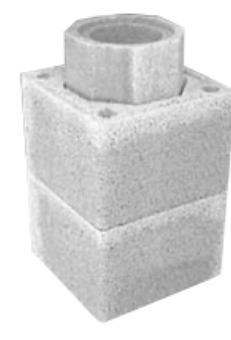

(b)

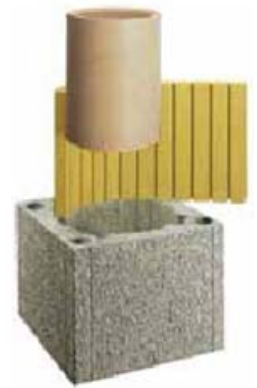

(c)

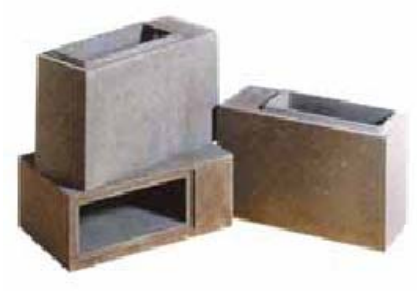

(d)

Şekil 4. İngiltere'de kullanılan baca elemanları. (a) Paslanmaz çelik baca sistemleri, (b) Pomza baca sistemleri, (c) Seramik baca sistemleri ve (d) Beton - tuğla bloklar [11].

Bacanın dumanı çekmesindeki başka bir etken bacanın formudur. Dairesel form en iyi çekişi sağlamaktadır. Şekil 5'te duman çekişi açısından en iyiden kötüye doğru sıralanmış formlar görülmektedir. Ayrıca baca iç yüzü pürüzsüz olmalı ve hiçbir zaman sıvanmamalıdır. Sıva isı nedeniyle dökülerek daha büyük sorunlara neden olabilmektedir.
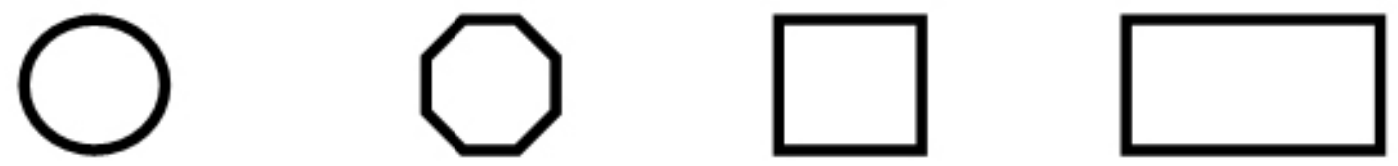

Şekil 5. Baca çekişinde formun iyiden kötüye doğru sıralanışı.

Ateş bacalarında kanal genişliğinin iyi çekiş açısından $13.5 \mathrm{~cm}$ olması gerekmektedir. Dikdörtgen kesitli bacalarda kısa kenarın uzun kenara oranının 2/3 olması iyi bir çekişi sağlamaktadır. Ateş bacası duvarlarının $500{ }^{\circ} \mathrm{C}$ 'ye kadar dayanıklı olması beklenmektedir. İyi bir çekiş için bir baca deliğine birden fazla ateş kaynağının bağlanmaması gerekmektedir [12].

\subsection{Bina tasarımında baca yerinin belirlenmesi}

Bacaların bina içerisinde bulunduğu yer de önem taşımaktadır. Bacanın mümkün olduğunca yapının iç bölümlerine yerleştirilmesi iyi bir çözümdür (Şekil 6). Bacanın dış duvarda yer alması durumunda yanma sürecinde ortaya çıkan sıcak gaz daha kolay bir şekilde soğuk hava ile karşılaşacak ve baca içinde yoğuşma oluşacaktır. Bu da bacanın sağlıklı çekişini engelleyebilecektir. Ayrıca bacanın dış duvar yüzeyinde bulunması isı kaybına da neden olabilecektir. Başka çözüm bulunamayıp yine de baca dış duvara yerleştirilecekse bu durumda bacanın dış duvara gelen yüzeyinin daha kalın bir duvar ile korunmaya çalışılması ve yalıtım yapılması sorunu biraz daha azaltacaktır (Şekil 7). Bina içinde bacaların tek bir noktaya toplanarak gruplandırılması 1sı kaybını azaltacağı 
için önerilen bir çözümdür. Bacalar için iyi uygulanmış plan örnekleri Şekil 8'de verilmiştir.

Bacanın çatının üzerinde yükseldiği bölüm için de 1sı kaybı ve yoğuşma söz konusu olabilmektedir. Bu durumda gerçekte duman çatı dışına çıkıncaya kadar 1sı kaybedecek ve yoğuşma oranı azalacaktır ama yine de bu bölüm için yalıtım sağlayacak önlemlerin alınmas1 gerekmektedir.

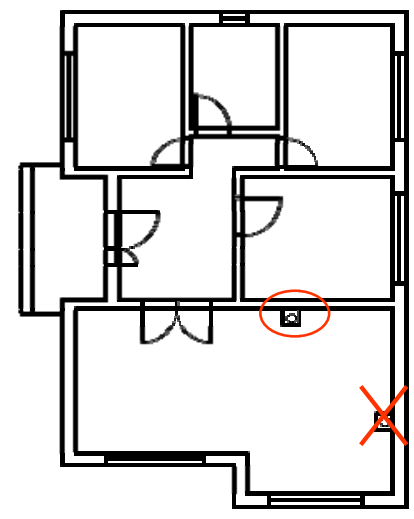

Şekil 6. Bacanın bina içinde planlanmasında iç duvarlara yerleştirilmesinin tercih edilmesi.

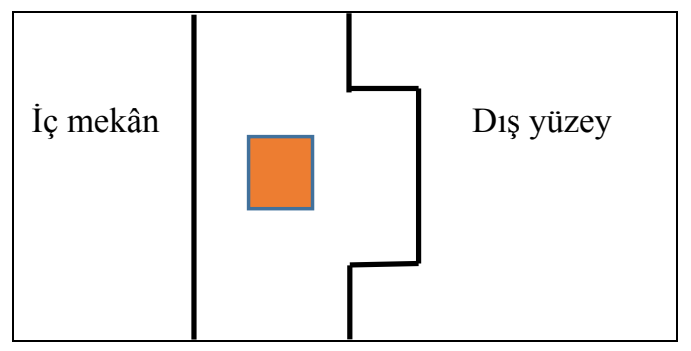

Şekil 7. Bacanın dış duvarda kalması halinde duvarın kalınlaştırılması.
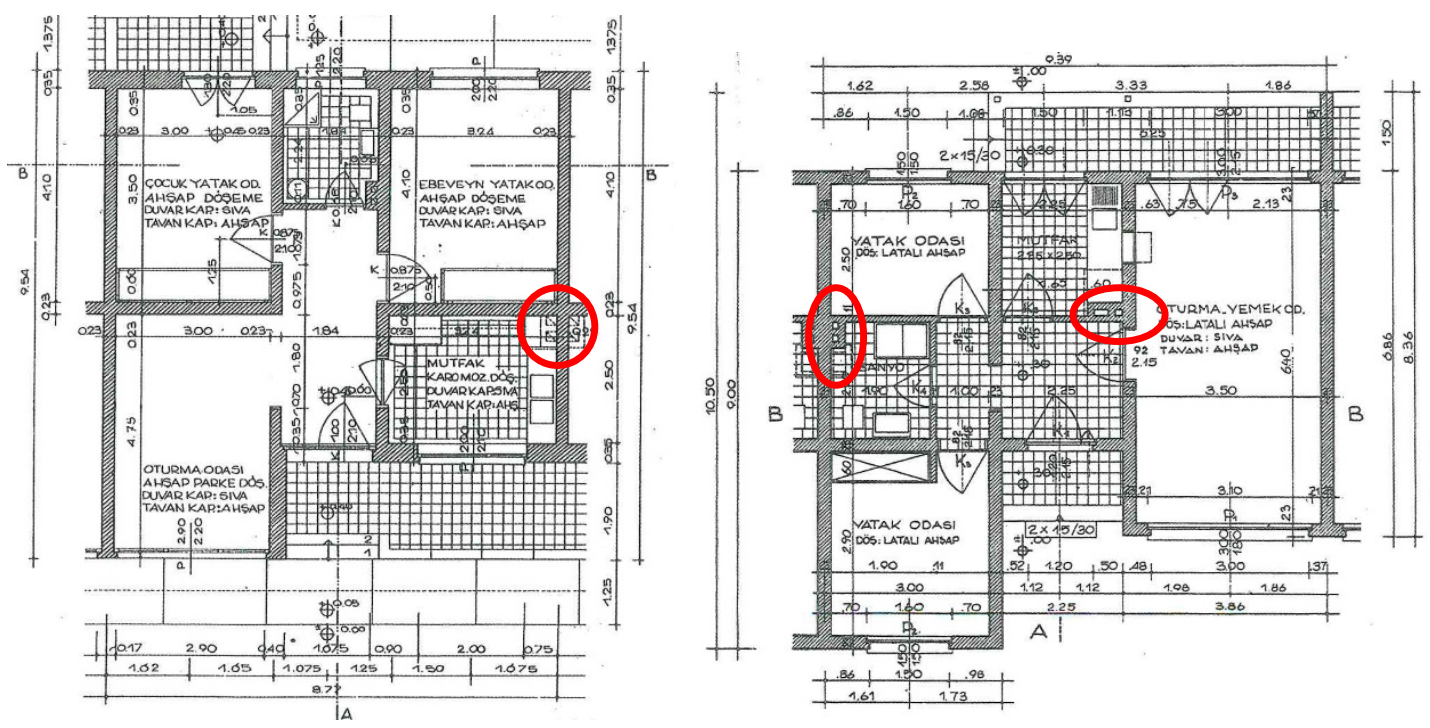

Şekil 8. Yapı içinde doğru planlanmış baca örnekleri [13]. 


\subsection{Bacanın çatıda konumlanması ve yüksekliği}

Baca elemanının çatıda konumlanması ve yüksekliği bacanın sağlıklı çalışabilmesi ve çatıya zarar vermemesi açılarından oldukça önemlidir. Bir çatıda binanın büyüklüğüne bağlı olarak birden fazla baca bulunabilmektir. Plansız Alanlar İmar Yönetmeliğinin Bacalar bölümünde (Madde 30) kaloriferli yapılarda sıcak su tesisatı yoksa banyo ve mutfakları ile oturma ve yatma hacimlerinden en az birinde baca bulundurulması, sobalı binalarda ise hela, koridor hariç tüm piyeslerde duman bacası yapılması zorunluluğu bulunmaktadır [14]. Bir yapida birden fazla baca bulunması durumunda bu bacaların yapım ve bacaların işleyişi açısından gruplandırılarak yapılmaları tercih edilmektedir. Baca gruplarında (birden fazla bacanın bir arada çözümlenmesi) hakim rüzgara göre yerleştirilme, rüzgarın geliş yönüne dik olmalı ve tüm baca rüzgardan etkilenecek şekilde A seçeneğinde olduğu gibi yerleştirilmelidir (Şekil 9), B seçeneğindeki gibi bir yerleşimde ise rüzgar baca çekişini yeterli düzeyde sağlayamayabilecektir.

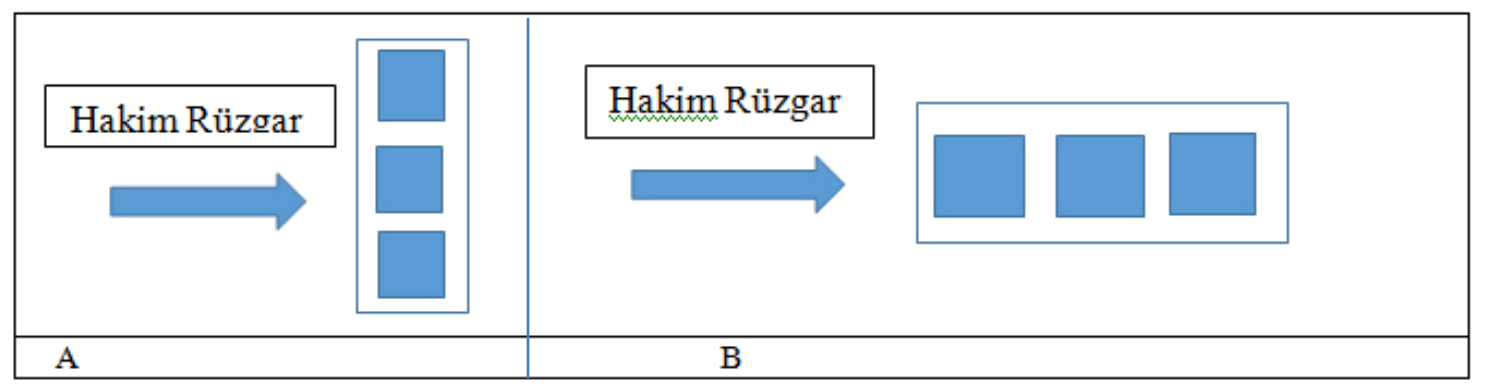

Şekil 9 A, B. Bacanın rüzgâra göre yerleştirilme tercihi.

Bacaların çatıya yerleştirilmelerinde de dikkat edilmesi gereken noktalar bulunmaktadır. Bacanın çatıya yerleşiminde mahya, eğik mahya ve dere gibi noktalardan kaçınılmalıdır. Aynı zamanda su akışı da göz önünde bulundurularak bacanın dar yüzü su eğimine getirilmeli ancak hakim rüzgarın etkisi daha ön planda tutulmalıdır (Şekil10).

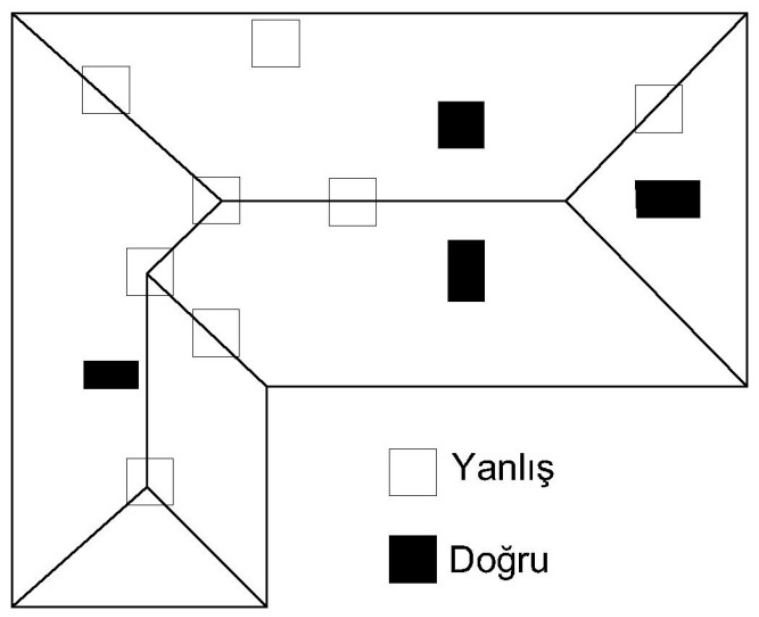

Şekil10. Bacaların çatı yüzeyinde düzenlenme yer ve şekilleri [15].

Bacanın çatı arasındaki bölümünde ahşap elemanlar ile arasında en az $20 \mathrm{~cm}$ mesafe olmalı ve söz konusu aralığa ısı yalıtım malzemesi konulmalıdır. Böylelikle çatıda bulunan ahşap elemanlar yangına karşı korunmuş olacaklardır (Şekil 11) [8]. 
Bacanın iyi bir çekişe sahip olabilmesi için yüksekliğinin mahyadan (çatının en yüksek noktası) en az 50-80 cm daha yüksekte olması gerekmektedir. Çatının çok geniş olması halinde bacanın mahyayı geçecek şekilde yükseltilmesi çok narin ve yüksek bir baca oluşumunu getireceğinden bu durumda bacanın çatı yüzeyinden 120-140 cm yükseltilmesi yeterli olacaktır (Sekil 12).

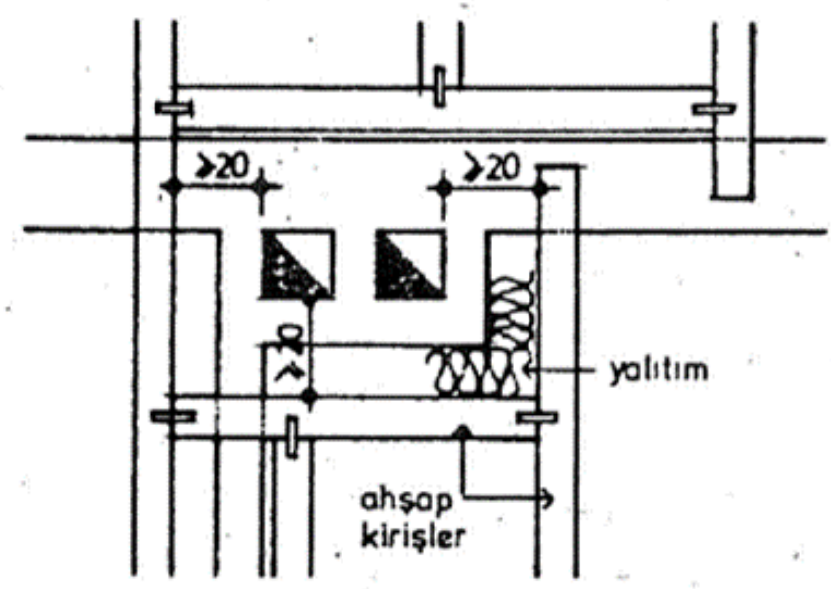

Şekil 11. Bacanın çatıdaki ahşap elemanlara göre konumlandırılması [8].
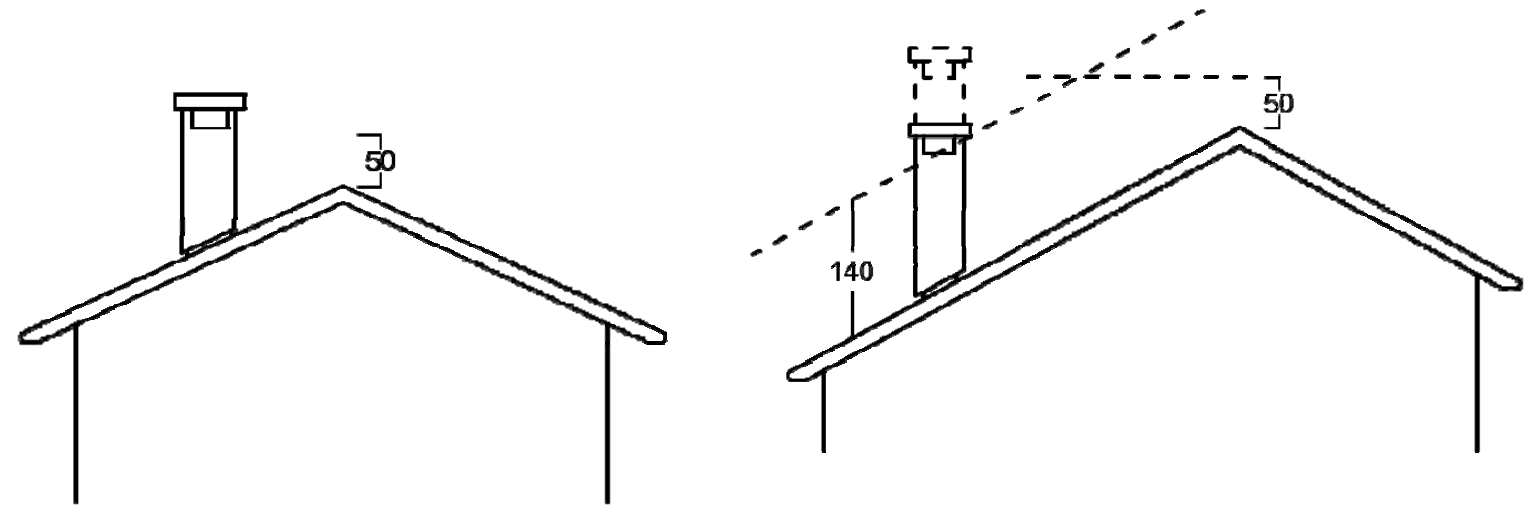

Şekil 12. Bacanın çatıda yükseltilme miktarları.

Binanın çevresinde yüksek yapılar ve engeller mevcut ise rüzgârlı havalarda hava akış1 yüksekten alçağa doğru olduğu için sürekli baca tepmesi olabilmektedir. Bu durumda baca ile yüksek yapı arasında en az $6 \mathrm{~m}$ uzaklık olmalıdır. Aynı zamanda teras çatılarda da baca yüksekliği en az $120 \mathrm{~cm}$ olmalıdır (Şekil 13).

Bir bacaya en fazla 4 soba deliği bağlanabilmektedir. Ancak her soba deliği arasında en az $30 \mathrm{~cm}$ aralık bulunmalıdır. Bacaların içlerinin temizlenmesi için de döşemeden 60-90 $\mathrm{cm}$ yükseklikte 18-20 cm'lik bir delik bırakılması gereklidir [16]. Bina çevresinde yüksek yapılar veya ağaç gibi engeller mevcutsa rüzgârın hava akışının sağlanabilmesi için bina bacası ile yüksek yapı arasındaki mesafenin yine en az 6 metre olması gerekmektedir (Şekil 14 a, b).

Sobalarda verimli bir yanma için etkili baca yüksekliği yapı içinden itibaren yeterli yükseklikte olmalıdır. Baca yüksekliği yeterli değil ise yanma verimli olamaz. Bu tür sobalarda sık aralıklarla baca gazı tepmesi olabilmektedir. İdeal yanma için etkili baca yüksekliği en az 3,5 metre, en fazla 5 metre olmalıdır (Şekil 15). Uzun bacalı binalarda, 
yoğuşmayı önlemek için baca malzemesi olarak taş, tuğla veya paslanmaz çelik kullanılması uygun görülmektedir.
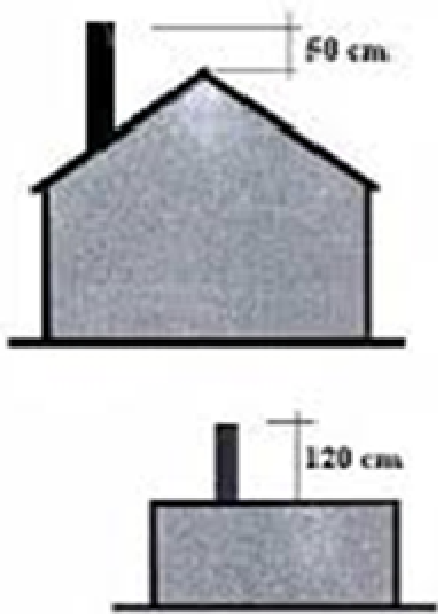
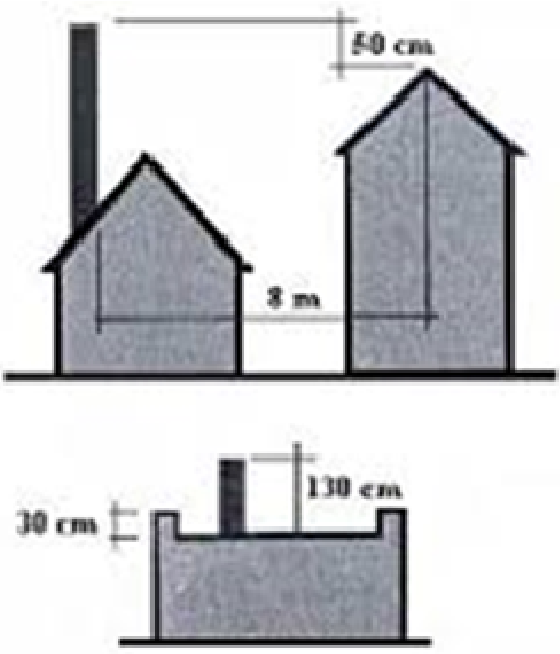

Şekil 13. Doğru baca uygulamasında baca yükseklikleri.
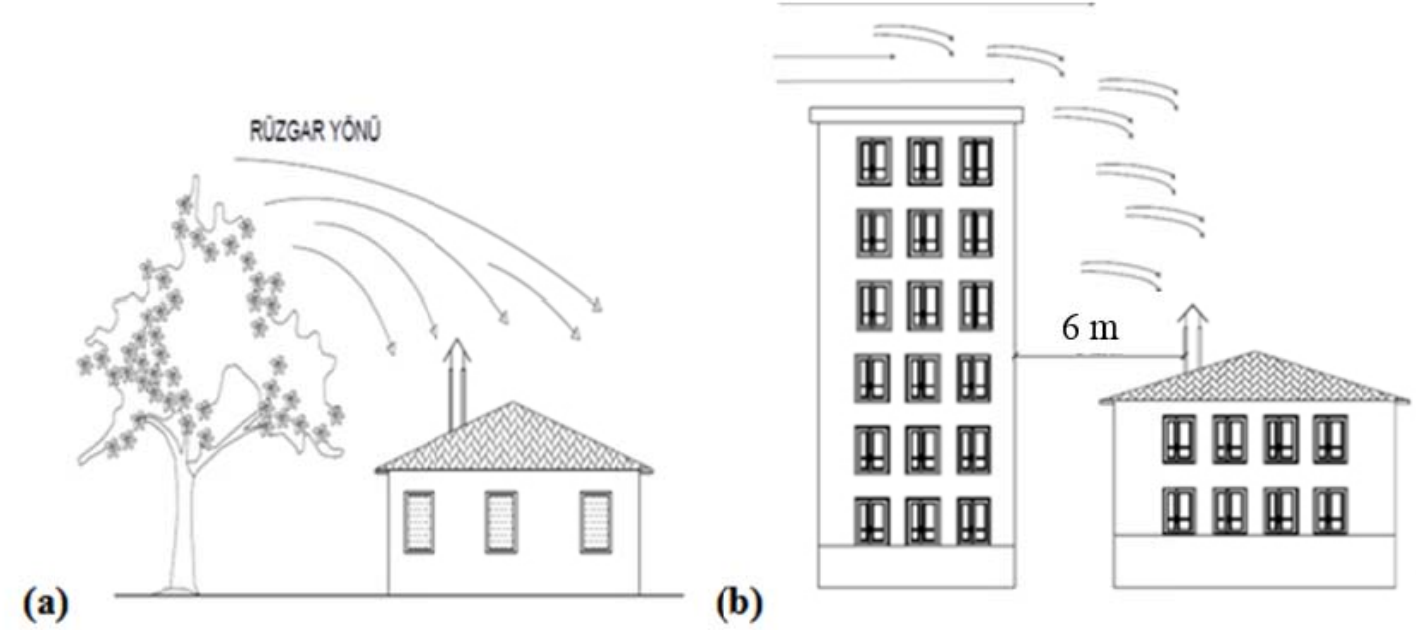

(b)

Şekil 14. a,b. Yüksek engellerin baca üzerine etkisi ve baca ile engel arasındaki mesafe.

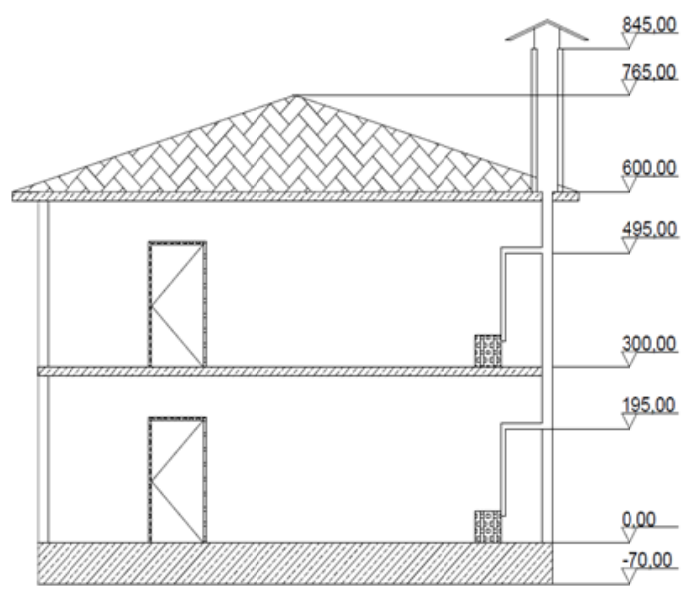

Şekil 15. Etkili bina yüksekliği ve baca başlı̆̆g. 
Bacalara, yağmur suları, kuşlar, ağaç yaprakları vb. maddelerin girmesini engellemek için mutlaka başlık kullanılmalıdır. İngiltere baca üreticileri derneği standardına göre verilmiş baca örtü elemanı örneği Şekil 16. da verilmektedir.

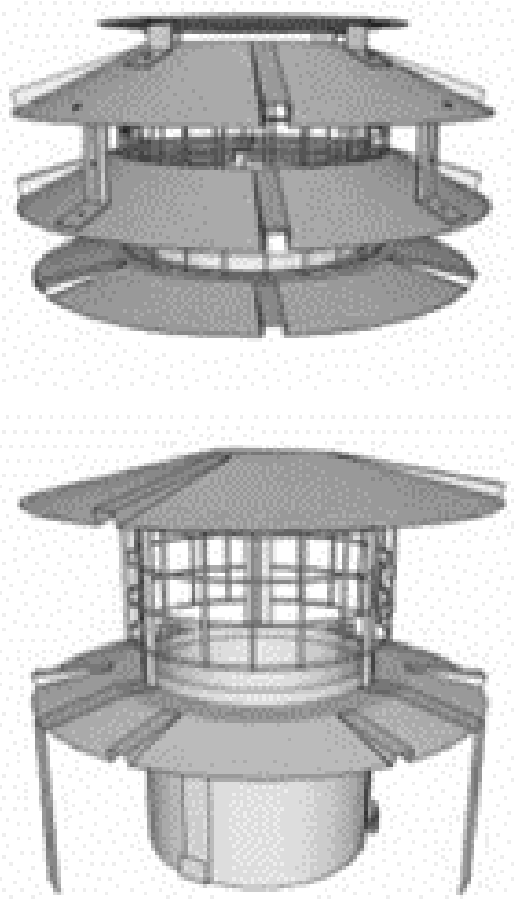

Şekil 16. Çelik baca bitiş elemanı kuş ve artık koruyucu [11].

\section{4. Çatı örtüsünde baca dibi detaylandırılması}

Bacanın çatı yüzeyi ile birleştiği noktada uygulanacak yalıtım oldukça önemlidir. Bacanın çatı ile arakesitinin iyi detaylandırılması gerekmektedir. Bu nokta hem baca duvarına su sızmaması açısından hem çatının suya karşı korunması açısından dikkat edilmesi gereken bir bölümdür. Şekil 17 a ve b'de baca dibi için detay uygulama örneği görülmektedir. $\mathrm{Bu}$ uygulama örneğinde çinko levha kaplama ile baca ve çatı yüzeyindeki arakesit suya karşı yalıtılmıştır. Şekil 17 a'da plan, iki yönde kesit ve görünüş ile uygulama detayı anlatılmaktadır. Şekil 17 b, çinko malzemenin baca duvarı ve çatı düzlemi ile nokta detaylarını göstermekte ve çinko levhanın baca duvarı ile birleşme detayını vermektedir.17].

Günümüzde yalıtım malzemeleri her geçen gün gelişmekte ve yaygınlaşmaktadır. $\mathrm{Bu}$ yeni ürünlerin kullanımları ve detaylandırılmaları da daha kolaydır, ancak zaman-zaman bakım yapılması gerekebilmektedir. Baca dibi bandı, bacanın taban dönüşlerinde su izolasyonu sağlaması için kullanılmaktadır. Baca kenarından akan suyu kiremit üzerine aktararak çatı altına geçmeden tahliyesini sağlar (Şekil 18). Arka tarafının tamamen su yalıtımında etkili butil yapışkan bandı ile kaplanmış olması sayesinde uygulama yerlerine kolayca yapıştırılır [18]. 

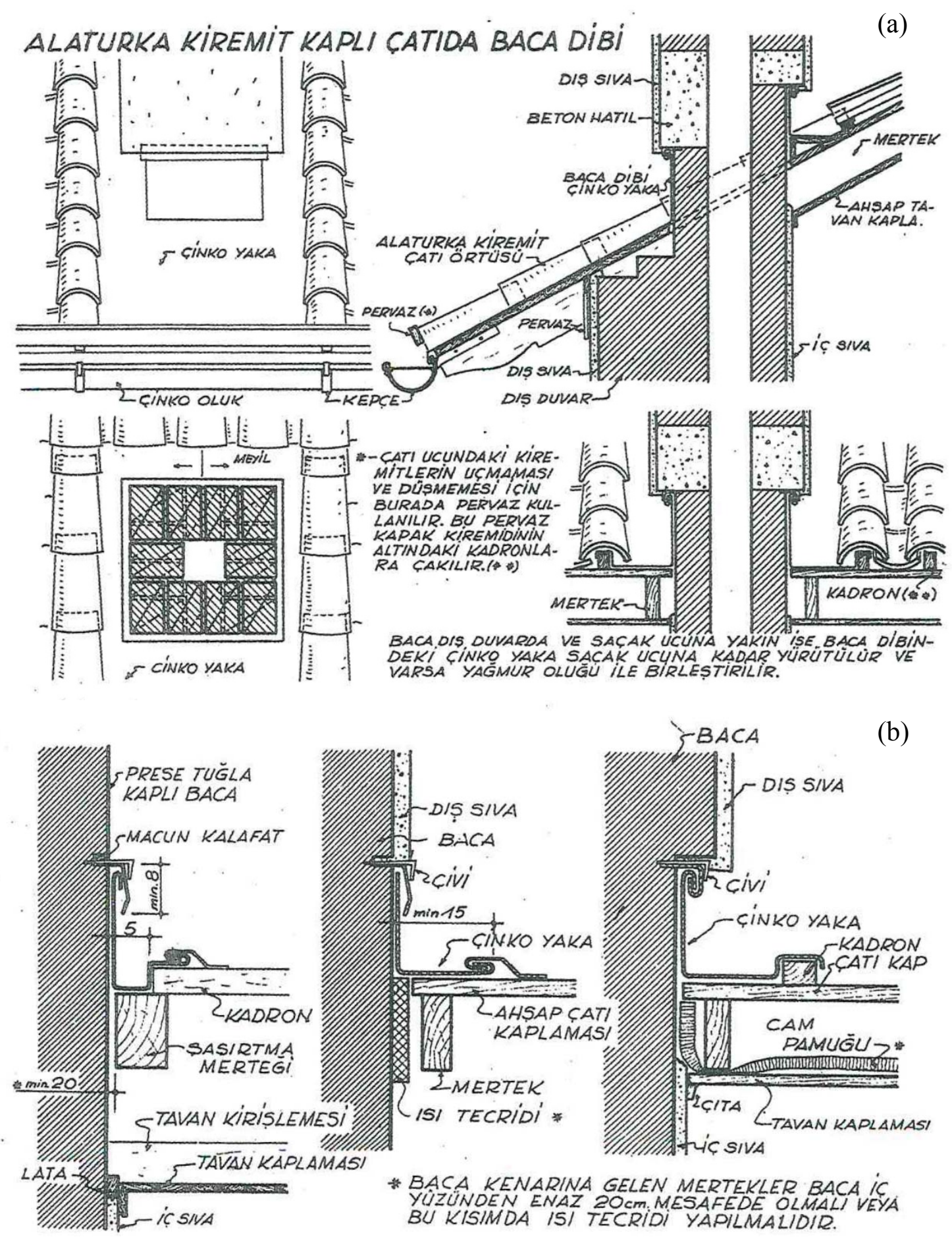

Şekil 17.(a) Baca dibinin çatı ile kesişimi (b) Baca dibi nokta detayı [17]. 


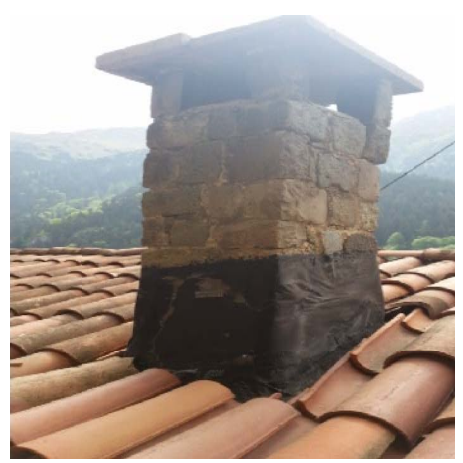

(a)

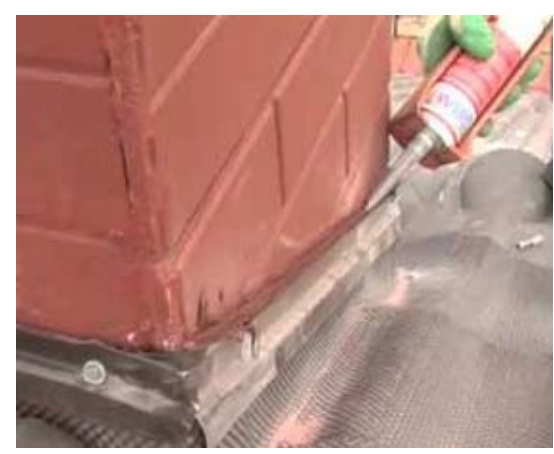

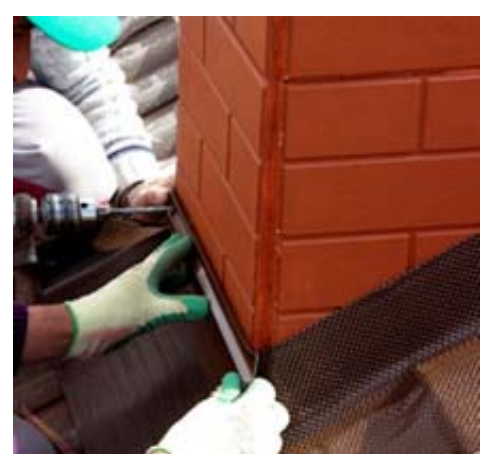

(b)

Şekil18. Çatıda su yalıtımı için baca dibi bandı uygulaması. (a) Poliüratan mastik uygulanması [19]. (b) Baca dibi bandı uygulama örneği [20].

\section{Bulgular}

Günümüzde inşaat teknoloji ve malzemeleri oldukça gelişmiştir. Her gün yeni bir malzeme ve uygulama yöntemi ile karşılaşılmaktadır. Bu koşullarda binalarda yapım kaliteleri de yükselmektedir. Bu duruma rağmen hala bilinçli olunmadığı için önemsenmeyen aslında yapımı zor ve pahalı olduğu için değil bilinçli yaklaşılmadığ için İhmal edilmişlikten kaynaklanan sorunlar ile karşılaşılmaktadır. Şekil 19'da baca yapım kalite ve şartları oldukça özenli inşa edilmiş bir örnek görülmektedir. Şekil 20'de görülen fotoğraflarda ise yükseklikleri, çevredeki yapılarla ilişkileri gibi açılardan baca yapım kurallarına uygun olmayan örnekler görülmektedir.

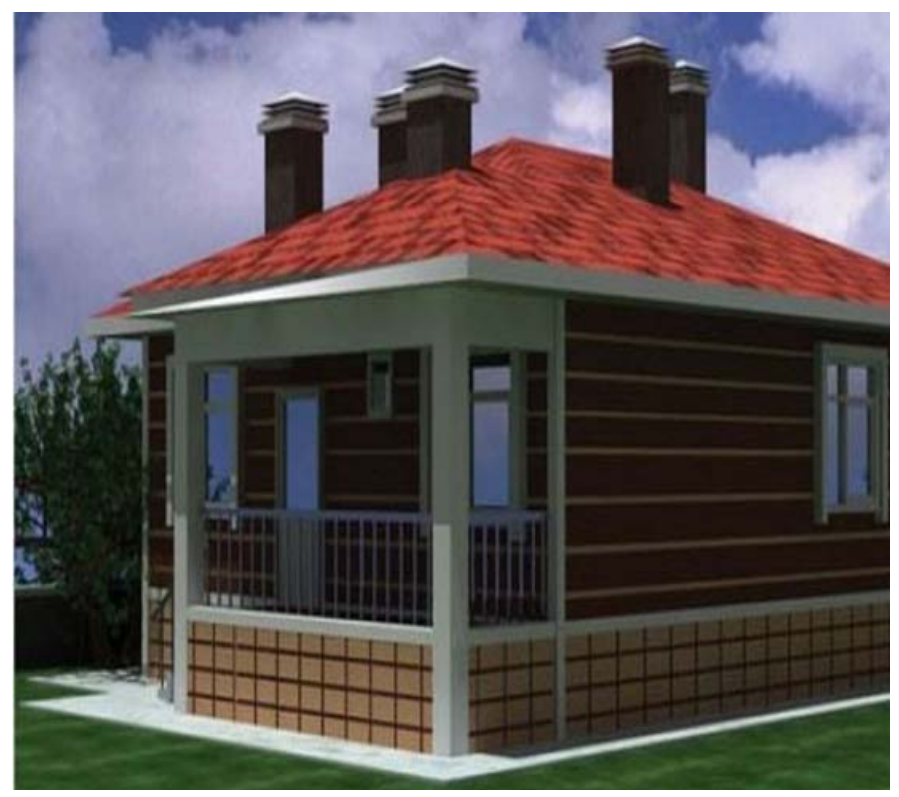

Şekil 19. Doğru baca uygulama örneği.

$\mathrm{Bu}$ örnekler daha da çoğaltılabilir, ancak önemli olan burada kullanıcı ve uygulayıcıların bina yapım kurallarına uygun davranma bilinçliliğine getirilmeleri, standartların ve yönetmeliklerin uygulanmaları ve kontrollerinin sağlanabilmesidir. 


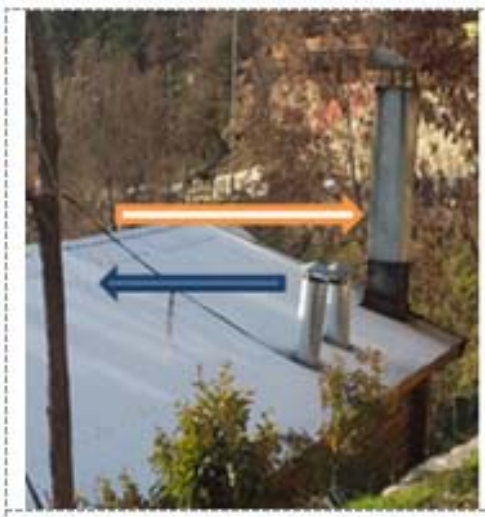

(a) Bacaların iyi çekiş yapabilmeleri için boylarının mahyadan yüksek olmaları gerekmektedir

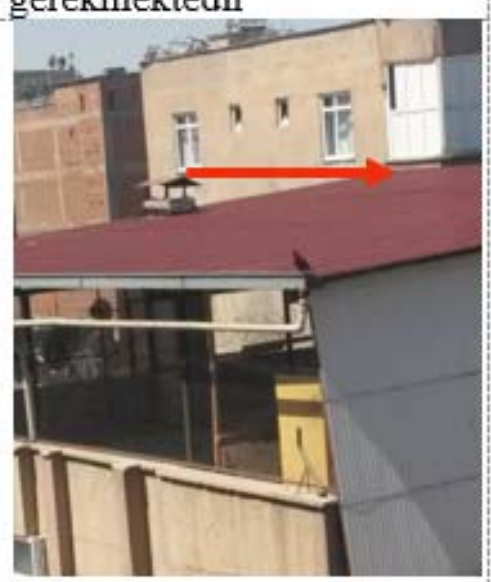

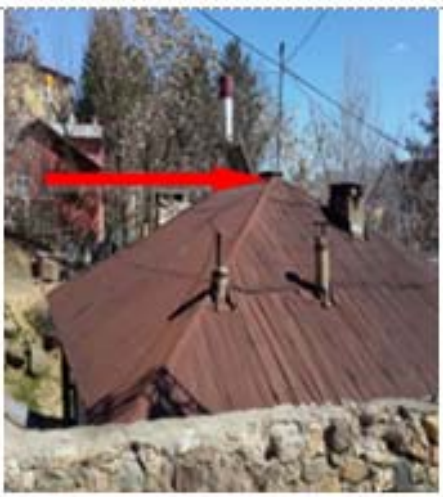

(b) Bir yapı çatısında yapilan bacalarin boyları en az 50-80 cm kadar çat1 ana mahyasının üstünde tasarlanmalidir.

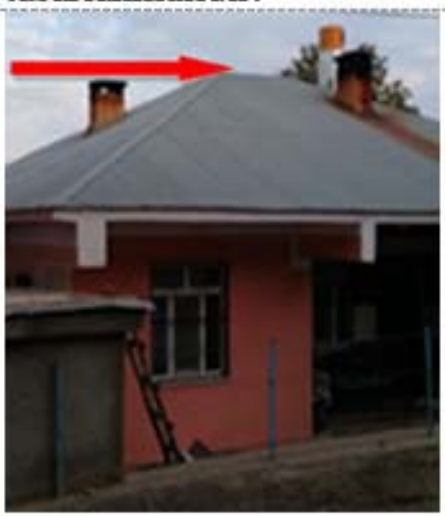

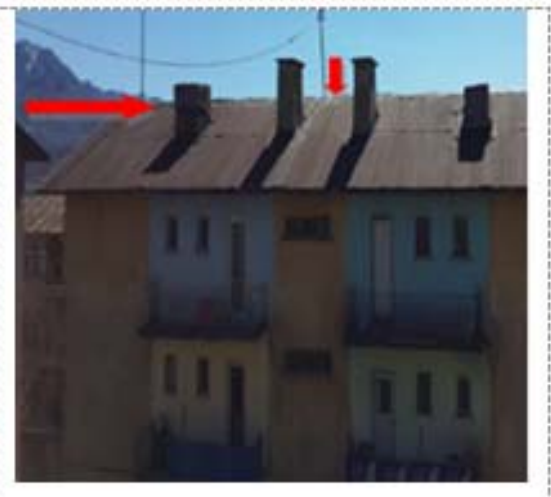

(c) Baca şapkası kullanılmamış ve boyları eşit yapılmamış, mahya yüksekliği sağlanamamış baca örnekleri.

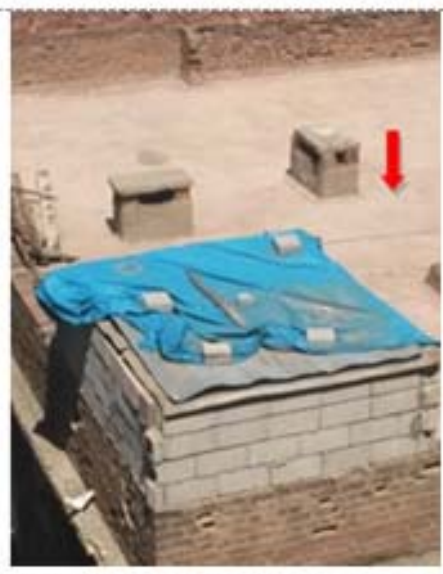

(d) Bacaların mahya yüksekliği altında kaldığı ve gerekli yüksekliğe ulaştırılmadığ 1 görülmektedir.

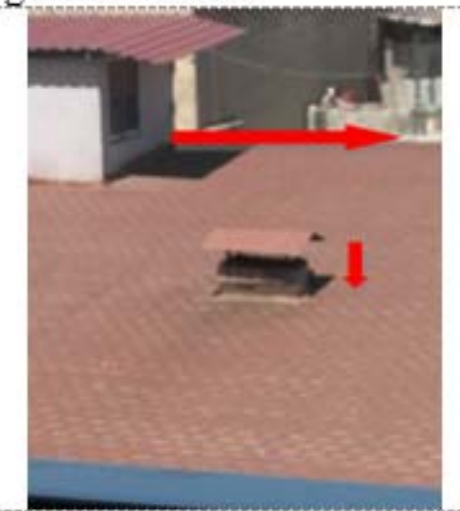

(e) Mahya seviyesi altındaki baca örneği.

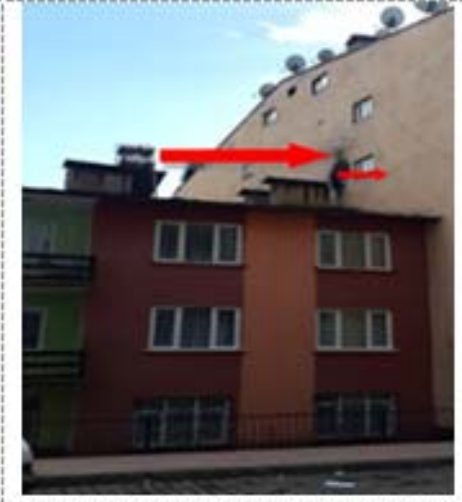

(f) Baca ile bitişik yap1 arasındaki mesafenin sağlanamaması ile ilgili örnek.

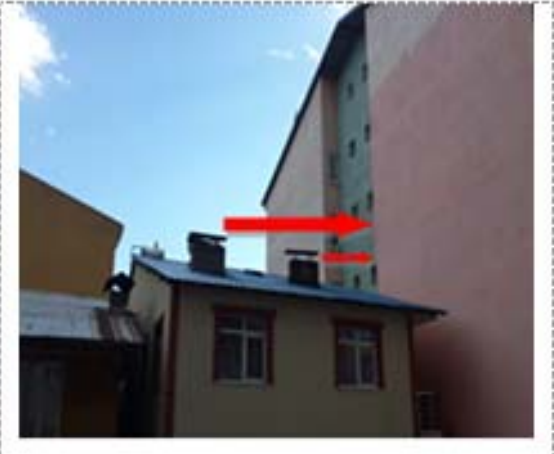

(g) Bitişik yapılarda baca ile yapi arasinda en az $600 \mathrm{~cm}$ uzaklık olmalıdır, bu şartın sağlanamadiğ

Şekil 20. Standartlara uygun olmayan baca örnekleri 


\section{Sonuç ve Öneriler}

Yaşama mekanlarında ateş bacaları günlük hayatın birer parçası gibidirler. Hem enerji tasarrufu hem kaliteli 1sınma ve sağlıklı yaşayabilme açılarından oldukça önemli yapı elemanlarıdır. Ancak yapım kaliteleri açısından bakıldığında pek çok sorun içerdikleri ve ölümle sonuçlanan olaylara neden olabildikleri görülmektedir. $\mathrm{Bu}$ nedenle düzenlenen yasa, yönetmelik ve standartların oluşturulmaları ve uygulanmaları hakkında gerekli hassasiyetin gösterilmesinin önemine dikkat çekilmesi gerekmektedir.

Ateş bacalarının yapımında kullanılan malzemeler ve yapım sürecinde dikkat edilecek noktalar bulunmaktadır. Bacaya verilecek form ve oluşturulacak baca grupları önemlidir. Bacaların binaların nerelerinde planlanmasının uygun olacağı ile ilgili kurallar bulunmaktadır ve planlama sürecinde kesinlikle göz önünde bulundurulmaları ileride olabilecek pek çok sorunu önleyebilecektir. Bacanın planlanmasında çatı yüzeyinde hangi noktalarda bulunacağı önemli görülmektedir. Bacanın, yapının çatısı ile ilgili olarak 1s1 ve su yalıtım detay ve uygulamaları hakkında uyulması gereken özellikler bulunmaktadır.

Dış ortamda bulunan bacanın üst örtüsünün bulunması gerekmektedir. Yine dış ortamda çevredeki yapılara, rüzgar yönüne ve mahya yüksekliklerine göre uyulması gereken kurallar bulunmaktadır. Bu kural ve özelliklere bilinçli yaklaşılması yaşanan sorunları elbette azaltacaktır.

Ülkemizde çok yaygınlaşmamış olmakla birlikte ölümle sonuçlanacak olayların önüne geçilebilmesi için karbonmonoksit sensörlerinin kullanımlarının yaygınlaştırılması da alınabilecek önlemlerden biridir. Bu uygulama en azından dumanın geri tepme olaylarında alarm ile kullanıcıları uyararak ölüm riskini ortadan kaldırabilecektir. Ayrıca rüzgar ve hava koşullarının riskli olduğu zamanlarda halkın uyarılması da alınacak önlemler arasında sayılmalıdır.

Çevremizde tanık olduğumuz sorunların çoğunun bilinçsiz yaklaşımlardan kaynaklandığı görülmektedir. Elbette ki tüm yapılarda olduğu gibi binaların bir parçası olan bacaların standartlara uygun tasarlanmaları ve mevcut yasalara uygunluklarının daha özenle kontrollerinin sağlanmaları gerekmektedir.

\section{Kaynaklar}

[1] Meredith T, ve Vale A., Carbon monoxide poisoning, British Medical Journal, 296, 6615, 77-79, (1988).

[2] Tunalı, L., Bilkent Üniversitesi Sağlık Merkezi, Karbonmonoksit zehirlenmeleri http://bilheal.bilkent.edu.tr/aykonu/ay2009/karbonmonoksit.htm, (19.12.2016)

[3] Ernst A., ve Zibrak, J. D., Carbon monoxide poisoning, The New England Journal of Medicine, 339, 22, 1603-1608 (2017).

[4] Erturhan Ü., Bacalardan kaynaklanan karbonmonoksit zehirlenmeleri ve önleme çalışmaları, Tekstil Mühendisliği Dergisi, 132, 61-65, (2012).

[5] Oymael, S., Su-rutubet ve yangın etkilerinin dayanım, malzeme seçimi ve bina tasarımı ile ilişkisi, Antalya Yöresinin İnşaat Mühendisliği Sorunları 
Kongresi, 22-23-24 Eylül 2005, Antalya, 312-321.

http://www.imo.org.tr/resimler/ekutuphane/pdf/11150.pdf, (24.04.2017).

[6] Uludağ E., Türkiye'de baca sorunu nedir niçin bacayı konuşuyoruz?, Doğal Gaz Semineri, 33-111

http://www1.mmo.org.tr/resimler/dosya_ekler/b0b33971890f1f1_ek.pdf (24.04.2017)

[7] Arığlu N. ve Hatipoğlu D. D., Çok katlı konut yapılarında şönt baca uygulama sorunları ve deprem etkisi, Çatı Cephe Fuarı-CNR, 25 -26 Mart 2005, http://www.catider.org.tr/pdf/sempozyum/bildiri_10.pdf, (24.04.2017)

[8] Erten E., Yapı Elemanları I-II Ders Notları, KTÜ Basımevi, Trabzon, 51$55,(1992)$

[9] Çevre ve Şehircilik Bakanlığı Yap1 Malzemeleri Yönetmeliği (89/106/EEC) https://www.csb.gov.tr/turkce/index.php?Sayfa=sayfa\&Tur=mevzuat\&Id=112 (25.04.2017)

[10] Yanlış bacalar ölüm saçıyor, Ertaş-Hart Seramik Baca Sistemleri A.Ş., BACADER http://www.ertas-hart.com.tr/yanlis-bacalar-olum-saciyor.html, (19.12.2016)

[11] BFCMA (British Flueand Chimney Manufacturers Association), 4-5, 6 http://www.hetas.co.uk/wp-content/mediauploads/BFCMA-General-Guidance10-12-12.pdf, (19.12.2016)

[12] T.C. Milli Eğitim Bakanlı̆̆ı MEGEP, İnşaat teknolojisi, baca, 4, 2006 http://hbogm.meb.gov.tr/modulerprogramlar/kursprogramlari/insaat/moduller/Ba ca.pdf (19.12.2016)

[13] Eldem, S. H., Yapı, DGSA Yapı Kürsüsü, Birsen Yayınevi, 1973

[14] Mevzuatı Geliştirme ve Yayın Genel Müdürlüğü Mevzuat Bilgi Sistemi e.mevzuat, Plansız alanlar imar yönetmeliği, bacalar, www.mevzuat.gov.tr/Metin.Aspx?MevzuatKod=7.5.4882...0...plansiz, (25.04.2017)

[15] İnşaat bölümü yapı dersleri arşivi, Bacaların yapım kuralları ve düzenleme şekilleri, $\quad$ http://ders.insaatbolumu.com/yapi-elemanlari/bacalarin-yapimkurallari-ve- duzenleme-sekilleri, (19.12.2016)

[16] Avcıŏglu, M.,Yapı Teknolojisi-1, Birsen Yayınevi, İstanbul (2011)

[17] S. H. Eldem, SoygenişM., Yapı 1-2-3-4, Birsen Yayınevi, (2005)

[18] Baca dibi ve duvar dibi yalıtım band1, Bulgu Makine ve Civata San. Tic. Ltd. Şti., $\quad$ http://www.bulgu.com/baca-dibi-ve-duvar-dibi-yalitim-bandi/urunler/46, (25.05.2016)

[19] Duvar baca dibi çözümü, Persan-Çat1-Cephe-Yalıtım Sistemleri http://www.persanyapi.com.tr/video.php?video=19, (19.12.2016)

[20] Persan - Duvar ve baca dibi çözümleri, RAF ürün dergisi, http://v1.raf.com.tr/urun_1908_persan---duvar-ve-baca-dibi-cozumleri.html, (19.12.2016) 